\title{
THE NATURE OF CORRUPTION AFFECTING ENTREPRENEURSHIP IN TRANSITION ECONOMIES: SOME LESSONS FROM MONTENEGRO
}

Nick Williams, Dragana Radevic, Cristian Gherhes, Tim Vorley

\section{Abstract}

The aim of this paper is to examine how the institutional environment impacts the nature of corruption affecting entrepreneurship in transition economies. Drawing on a survey and in-depth interviews with entrepreneurs in Montenegro, the paper finds that corruption is a pervasive presence which has not been ameliorated despite economic reforms. Montenegro is a transition economy which has made significant strides in terms of creating a more open market economy. However, reforms have often overlooked corruption which remains prevalent, and the institutional environment has left space for officials and entrepreneurs to engage in corrupt practices. The paper shows that although it takes different forms, corruption can be viewed as a cultural impediment even if the majority of entrepreneurs are not exposed to it.

Keywords: Corruption, Entrepreneurship, Institutions, Transition economies

\section{INTRODUCTION}

Entrepreneurship is regarded as a catalyst of economic development in transition economies (Smallbone and Welter 2001; Puffer, McCarthy, and Boisot 2010). Yet corruption, which is often associated with transition economies, represents a significant challenge to moves towards open competitive markets (Manolova, Eunni, and Gyoshev 2008; Tonoyan et al. 2010; Estrin and Mickiewicz 2011; Imami 2012). Where institutions are weak, entrepreneurs can become exposed to and embroiled in corrupt practices (Xheneti, Smallbone, and Welter, 2012). As a result, corrupt practices can detract from more productive forms of entrepreneurial activity, and where corruption is deep-seated there are often wider economic and social ramifications. Although entrepreneurship is often portrayed as an individual endeavour, it is important to recognise that it both affects and is affected by the institutional environment which governs and directs economic activity (Acs, Desai, and Hessels, 2008; Bruton, Ahlstrom, and Obloj, 2008). As a corollary, institutional arrangements which create space for corrupt practices can stymie more productive forms of entrepreneurial activity,
Nick Williams, PhD

Associate Professor in Enterprise

Centre for Enterprise and Entrepreneurship Studies, Business School, The University of Leeds

E-mail: n.e.williams@leeds.ac.uk

Dragana Radevic, $\mathrm{PhD}$

Associate Professor in Institute for Entrepreneurship and Economic Development, University of Donja Gorica, Montenegro

E-mail: dragana.radevic@udg.edu.me

Mr Cristian Gherhes, Doctoral researcher Centre for Regional Economic and Enterprise Development, Management School, The University of Sheffield

E-mail: cagherhes1@sheffield.ac.uk

Tim Vorley, PhD

Professor of Entrepreneurship

Centre for Regional Economic and Enterprise

Development, Management School

The University of Sheffield

E-mail: tim.vorley@sheffield.ac.uk 
with wider ramifications for the economy and society (Chowdhury, Audretsch, and Belitski, 2015).

This paper finds that entrepreneurs in formerly centrally planned transition economies are frequently unable to operate beyond the realms of corruption. While this is the case in the larger transition economies of Eastern Europe (Vorley and Williams 2016), in the smaller, newly independent states corruption is common. Examining the nature of corruption affecting entrepreneurs in a transition economy, the paper demonstrates that part of what holds back entrepreneurship and its ability to contribute to economic development in these localities is partly the prevalence of corruption. While corruption is often seen as operating at the political or big business level (Round and Williams 2010), the paper highlights that corruption is faced by all entrepreneurs irrespective of the size of their ventures, and impacts at different points along their entrepreneurial journey, but has differential impacts on entrepreneurs according to the stage of their business activity (i.e. start-up or established, surviving or growing) and the size/value of their business. In starting a business, entrepreneurs are required to comply with numerous regulations, which exposes them to opportunistic petty corruption by low level bureaucrats. As their businesses grow, the nature of corruption is often more organised, involving kickbacks to political officials and/or extortion from more established 'tycoon' entrepreneurs. Some entrepreneurs use strategies to avoid corruption (Hudson et al. 2012), some accept it as a normal aspect of the culture, while others engage in it as perpetrators (Vorley and Williams 2016). As such, the central research question in this article is: "How does the institutional environment impact the nature of corruption affecting entrepreneurs in transition economies?" In answering this question, the paper finds that the institutional arrangements see corruption prevail, with entrepreneurs engaged and embroiled in corrupt practices whether by necessity or opportunity in different ways and at different stages of the business.

The empirical focus of the paper is Montenegro, a transition economy facing significant levels of corruption, which hinders productive entrepreneurship and is detrimental to economic development (Transparency International 2016; World Economic Forum 2016). Montenegro therefore provides an appropriate context for studying the nature of corruption affecting entrepreneurship. The paper highlights lessons from a transition economy but also to draw out implications for other countries seeking to develop more effective institutional frameworks which can reduce corruption and foster entrepreneurship. Our contribution is to show that in small transitioning economies such as Montenegro the institutional environment has not developed to the extent that it counteracts corruption. As such, perceptions of corruption are affected by negative experiences and the stories of others, even though most entrepreneurs do not experience corruption on a day-to-day basis. Given the size of the economy, corruption is often not linked to money, but rather nepotism. Where entrepreneurs engage in or are affected by corruption, it will most likely be through networks being used to speed up processes or by getting a preferential deal. Financial corruption only really affects large businesses with links to government, and the majority of entrepreneurs do not experience it.

The remainder of the article is structured as follows. Section 2 frames the study in terms of academic debates on corruption and entrepreneurship in transition economies. Section 3 introduces the institutional environment in Montenegro and sets out the methodological approach of the empirical project. Section 4 discusses the findings, highlighting the importance of informal institutions and networks, and how they represent an important aspect of the institutional landscape which affects entrepreneurial behaviours. Lastly, the article concludes by reflecting on the findings, and considers the wider implications for strengthening the institutional environment of Montenegro and other transition economies.

\section{LITERATURE REVIEW \\ The institutional environment and corruption}

Corruption is a multidimensional concept, the causes of which are diverse. It can be understood as a structural problem relating to political-economy, sociocultural issues or a combination thereof (Luo 2005; Transparency International 2016). The literature demonstrates that there are numerous causes of corruption, ranging from the impact of national wealth (Paldam 2002; Treisman 2000), the size of government (Montinola and Jackman 2002), income distribution and poverty (Paldam 2002), trade openness (Broadman and Recanatini 2000), inflation (Paldam, 2002), economic freedom (Goel and Nelson 2005), political stability (Treisman 2000), government regulations (Gerring and Thacker 2005), gender (Swamy et al. 2001) and an economy's competitiveness (Shleifer and Vishny 1993). These wide-ranging causes show that researchers have sought to categorise corruption in different ways to understand how it relates to other social, political and economic processes.

Moreover, the context in which entrepreneurship occurs is heterogeneous (Acs, O'Gorman, C., and 
Szerb, 2007; Puffer, McCarthy, and Boisot 2010) and the institutional framework that prevails is fundamental to shaping entrepreneurial orientation, new venture creation, aspirations, perceptions and, ultimately, growth (Welter 2011; Doern and Goss 2014; Efendic, Mickiewicz, and Rebmann, 2015). Entrepreneurs are significantly affected by the institutional environment and, if institutions are weak, entrepreneurs can become exposed to and embroiled in corrupt practices (Basu, Estrin, and Svejnar, 2005; Xheneti, Smallbone, and Welter, 2012). As such, entrepreneurial activities can usefully be considered through the prism of the formal and informal institutions in which they occur. Institutions affect both individuals and organisations, and influence decision-making by signalling which choices, norms and behaviours are normalised and socialised within a society (Ahlstrom and Bruton 2002; Tonoyan et al. 2010). Consequently, institutions have an impact on the cultural perceptions which shape behaviour, and provide the 'rules of the game' within which individuals and organisations operate and compete (North 1990), affecting organisational behaviour by constraining and defining which actions are acceptable and supportable both within and between organisations (Tonoyan et al. 2010).

Formal institutions can be defined as the rules and regulations which are written down or formally accepted and give guidance to the economic and legal framework of a society. Informal institutions can be defined as traditions, customs, societal norms, culture and unwritten codes of conduct. These norms and values are passed from one generation to the next and can therefore be resistant to change (Bruton, Ahlstrom, and Obloj, 2008). Indeed, Estrin and Mickiewicz (2011) assert that changes in informal institutions may take a full generation. Research on entrepreneurship in transition economies has increasingly taken into account the nature of the institutional environment (Ahlstrom and Bruton 2002; Acs, Desai, and Hessels, 2008). Pejovich $(1999$, p.171) explains that, in transition economies, the incentives created by changes in formal rules often conflict with the prevalent informal rules, and therefore the interaction between formal and informal institutions will "reduce the production of wealth in the community". Moreover, formal and informal institutions are viewed to interact in two key ways, either by complementing or substituting each other (Welter and Smallbone 2011). Informal institutions are complementary if they create and strengthen incentives to comply with the formal rules, and thereby plug gaps in problems of social interaction and coordination, and enhance the efficiency of formal institutions (Baumol 1990; North 1990). Where informal institutions substitute formal institutions, individual incentives are structured in such a way that they are incompatible with formal ones, and exist in environments where formal institutions are weak or not enforced. For example, entrepreneurs draw on extensive networks that are governed by informal norms to circumvent formal and bureaucratic procedures, such as jumping of queues, arranging preferential agreements for loans or settling disputes (Ledeneva 1998; Bruton, Ahlstrom, and Obloj, 2008; Williams and Yang 2017). Whether entrepreneurs are assuming the role of bribe-payers or bribe-takers, the outcome sees corruption embedded in the institutional arrangements. This means that corruption can become a cost and act as a disincentive to (productive) entrepreneurship. Consequently, entrepreneurs often seek to develop contacts and social networks to mitigate the effects of corruption. However, this can potentially see them become embroiled with corruption as a beneficiary (Aidis, Estrin, and Mickiewicz, 2008). This can mean increasing the transaction costs associated with doing business unless they develop strategies to limit the negative effects of corruption (Anokhin and Schulze 2009). While the returns to entrepreneurship will be lower when corruption is higher, Estrin, Korosteleva, and Mickiewicz (2013) hypothesise that this varies according to the type of entrepreneur and enterprise. The disincentive effects of corrupt practices will be more pronounced for high-growth aspiration entrepreneurs, yet the impact on low-growth and subsistence entrepreneurship will be limited. As such, Welter and Smallbone (2011) assert small(er) enterprises are less likely to encounter corruption than larger firms, meaning that they often attract the attention of corrupt officials (Hunt and Laszlo 2012). However, even if larger businesses are more visible, they can be less adversely affected by corruption, as the gains can offset the costs (Anokhin and Schulze 2009).

\section{Formal institutions and corruption}

Extant research suggests that the institutions governing the economic environment in transition economies impose costly and bureaucratic burdens on entrepreneurs, which increase uncertainty as well as the operational and transaction costs of doing businesses (Aidis, Estrin, and Mickiewicz, 2008; Tonoyan et al. 2010; Puffer, McCarthy, and Boisot 2010; Budak and Rajh 2014). This is particularly evident with respect to financial institutions. Entrepreneurs in such settings can often be faced with incoherent and constantly changing business regulations (Manolova and Yan 2002; Aidis, Estrin, and Mickiewicz, 2008), meaning that, for example, they are unable to calculate their tax 
bills due to changing tax codes (Tonoyan et al. 2010). In relation to accessing finance, Smallbone and Welter (2001) contend that banks tend to favour larger businesses and are generally less willing to finance small enterprises. Obtaining credit is a major constraint on entrepreneurial activity in emerging economies (Aidis, Estrin, and Mickiewicz, 2008), and as a result entrepreneurs and small firms often either have to resort to the informal credit markets or resort to bribing bureaucrats to secure the access to capital (Guseva 2007). Therefore, entrepreneurs in such economies look for opportunities whereby they can get around the constraints created by formal financial institutions.

A stable legal framework with well protected property rights also promotes planning and growth, as well as preventing the ad hoc expropriation of the fruits of entrepreneurship (Baumol 1990; Henrekson 2007). However, the experience of entrepreneurs in many emerging economies has been that the juridical system is incapable of adequately protecting property rights and of resolving business disputes (Manolova and Yan 2002). This is despite reforms being made whereby former Soviet countries have adopted written legal frameworks akin to those of more developed economies, including property, bankruptcy, contracts and taxation laws (Smallbone and Welter 2001; Aidis, Estrin, and Mickiewicz, 2008). However, these reforms have been ineffective in many cases, instead leading to inefficiencies and bureaucracy which means that going to court to settle a business dispute can be time consuming and costly (Luo and Junkunc 2008). In addition, there is a perception that the regulatory and legislative institutions are often themselves corrupt, which means that many entrepreneurs will avoid turning to the courts to settle disputes (Tonoyan et al. 2010). In such circumstances entrepreneurs often turn to informal networks to compensate for the failure of the legal system, for example by using connections to bend the rules or paying bribes that break them (Aidis and Adachi 2007). While entrepreneurs seek to mitigate the effects of corruption through their networks, this can go full circle and see them become embroiled with corruption as a beneficiary (Aidis, Estrin, and Mickiewicz, 2008). In such circumstances the prospect of engaging in illegal deals or corrupt activities will depend on the anticipated cost and probability of being punished (Becker 1968), and therefore entrepreneurs build the punitive costs into their pricing when planning a corrupt deal.

\section{Informal institutions and corruption}

With the fall of the Iron Curtain, countries in Eastern Europe and the former Soviet Union experienced dramatic changes in their political, economic and legal institutions. However, the informal norms and values which had been learned and adopted during the socialist years have continued to prevail. As a consequence, informal institutions have not complemented but rather have supplemented changes in the formal institutional environment (Guseva 2007). In environments with weak or uncertain formal institutions, entrepreneurs can lack trust and confidence in rules and regulations (Efendic, Pugh, and Adnett, 2011) and will be guided and governed by informal codes of conduct (Ahlstrom and Bruton 2002). Ledeneva (1998, p.213) finds that entrepreneurial behaviours in many emerging economies continue to be shaped by the rules inherited from the socialist period such as "what leads to success is always correct". Societies have therefore emerged in the former Soviet countries where informal institutions, i.e. the unwritten codes and social conventions, dominate the formal institutions. These informal institutions are often manifested at the individual level. Taken for granted behaviours are learned by living or growing up in a community or society, and are therefore specific to that culture (Scott 2007). This engenders a predictability of behaviour in social interactions, which are reinforced by a system of rewards and sanctions to ensure compliance. DiMaggio and Powell (1983) describe how this sees informal norms established over time.

The social norms and perceptions of behaviour associated with these informal institutions are important determinants of whether corrupt practices are accepted or not (Budak and Rajh 2014). For entrepreneurs, the likelihood of becoming embroiled in corruption is affected by the perception of how many other individuals in the society are engaged in corrupt arrangements (Andvig and Moene 1990). If corruption is rife or perceived as a norm, the expectation will be that the 'moral costs' are low in terms of social sanctions. Indeed, Rose-Ackerman (2001) suggests individuals in the post-Soviet transition states often justify their own corrupt behaviour by the pervasive nature of corruption in their own lives. As such, Tonoyan et al. (2010) posit that corruption may be rationalised for to two reasons: first, entrepreneurs who share the view that the "good" ends justify the means may be more willing to engage in corruption, with the "good" ends referring to economically better outcomes (e.g. receiving a public contract, saving on taxes, getting a license), which may be achieved via "dirty" means (e.g. bribing bureaucrats/public officials); and second, the probability of corruption being high in countries where the majority diverges from legal norms. 


\section{Institutional interplay and corruption}

It is clear that both the formal and informal institutions present within a country can see corruption normalised, as corrupt behaviours spread and intensify to a point where it is expected and accepted although not necessarily morally approved (Spicer 2009). Indeed, it is the interplay between formal and informal institutions which allows corruption to persist (Vorley and Williams, 2016). The process by which corruption is normalised is described by Ashforth and Anand (2003) in three steps: institutionalisation, rationalisation and socialisation, and is equally applicable to corruption in the public and private sector. In the case of emerging post-socialist economies, a longstanding culture of misusing public power for private gain has existed, which has been appropriated into the private sector during transition. In this way, corruption has become normalised as a rule of the game, being embedded further as corrupt behaviours and practices are perpetuated through social structures and ideologies. Consequently, corruption is often not regarded as a deviant practice, but rather becomes accepted as a fact of life. This, in turn, impacts on entrepreneurs, some of whom accept corruption and act strategically to use it to their advantage, while others who may seek to avoid corruption inadvertently become subject to it as a result of paying bribes or incurring the non-monetary cost of not paying bribes.

The challenges associated with institutional development are common, albeit to differing degrees across transition economies (Efendic, Pugh, and Adnett, 2011; Krasniqi and Mustafa 2016). As Cowen and Coyne (2005) state, developing effective institutions is particularly difficult in post-war environments when concurrent with wider societal reconstruction. Building effective institutions and coordinating public policy in transition economies poses a very real challenge to realising a path towards economic growth and development. The remainder of the paper examines institutional reform and its impacts on corruption and entrepreneurship in Montenegro as a transition economy. Our paper finds that, despite some progress being made in strengthening its formal institutions, reforms have not adequately tackled corruption, which remains an everyday part of an entrepreneur's life. In fact, corruption is normalised, with many people not seeing illegal activities as 'corrupt' per se.

\section{EMPIRICAL FOCUS AND METHOD}

The empirical focus is the institutional environment in Montenegro, a small upper middle-income country in South Eastern Europe. Formerly part of the Federal
Republic of Yugoslavia, Montenegro is a relatively new transition economy having declared its independence from Serbia in 2006 (Andelic, Cosic, and Dakovic, 2010). In progressing towards a more open market economy, Montenegro faces many challenges such as corruption generated by the misalignment between formal and informal institutions known as institutional asymmetry (Williams and Vorley 2015), institutional vacuums filled by informal practices or "corrupt efforts" that influence the formation of laws, rules and regulations (Hellman and Kaufmann 2001, p.2), which hinder productive entrepreneurship.

Previous research on Montenegro and similar transition economies from South Eastern Europe has identified various barriers to entrepreneurship amongst which financial and fiscal burdens, human resource barriers caused by ineffective employment regulation, and an underdeveloped entrepreneurship culture are some of the most common (Pinto 2005; Bobera, Lekovic, and Berber, 2014). Perceived opportunities for start-up, fear of failure, and social support for entrepreneurial activities are also suffering due to deteriorating business conditions, and institutional barriers continue to stymie productive entrepreneurship. Moreover, there are significant challenges to developing effective entrepreneurship policies, such as resource scarcity, institutional turbulence, ineffective institutional cooperation and coordination, informal economic activities, complicated tax systems, access to finance by SMEs, and inadequate business support programmes (Pinto 2005; Williams, Franic, and Dzhekova, 2015). Indeed, the European Commission (2014) identifies the regulatory and legal environment, contract enforcement, administrative costs and barriers, and privatisation procedures as areas where further improvement is required.

Montenegro became an EU candidate country in 2010 and started accession negotiations in 2012, part of which involves a commitment to tackling corruption (European Commission 2014). In Montenegro corruption was widespread even before independence. Montenegro witnessed what Hellman and Kaufmann (2001) refer to as 'state capture', whereby private interests exert influence on public officials through bribes and kickbacks to shape state laws, policies, and regulations to their own advantage. State capture thus occurs when the boundaries between private and political interests are blurred, undermining and sometimes replacing "legitimate and transparent channels of political influence and interest intermediation" (World Bank 2000, p.3). Montenegro experienced state capture through a combination of economic and political transition, whereby private interests used power vacuums to shape the new rules of the game, international 
sanctions, privatisations and a general lack of transparency and effective control mechanisms (Uzelac 2003). The privatisation process in Montenegro led to value destruction and was detrimental to productive entrepreneurship as managers and politically connected individuals took advantage of weak institutions and liquidated more productive firms as well as smaller firms through asset stripping (Koman et al. 2015). Therefore, the seed of corruption started to germinate long before Montenegro's independence, and continues to hinder institutional reforms and the transition to a market economy.

The Corruption Perceptions Index classifies Montenegro as one of the most corrupt states in Europe, ranking 64th out of 176 countries, significantly higher, however, than its neighbour Albania (Transparency International 2016). The World Economic Forum (2016) places Montenegro on the $82 \mathrm{nd}$ place out of $138 \mathrm{global}$ economies in terms of overall competitiveness, twelve places lower compared to the previous year, with corruption being in the top five most problematic factors for doing business. Moreover, the institutional environment ranks lower in areas such as organised crime, judicial independence, property rights, and business costs of crimes and violence. Requiring only 6 procedures and taking just over one week to start a business, Montenegro ranks 51st of the 190 countries surveyed by the World Bank (2017) in terms of the ease of doing business, significantly higher than Albania, and made significant improvements in enforcing contracts and trading across borders. However, although improvements have been made, the country still ranks lower in dealing with construction permits, paying taxes, and registering property, areas which can give rise to corrupt practices to reduce the burden or to speed up processes. Ranking 83rd out of $180 \mathrm{global}$ economies in the 2017 Index of Economic Freedom, Montenegro continues to face high levels of corruption which remains pervasive (Heritage Foundation 2017). Thus although Montenegro has made some progress towards aligning its institutions with the European Union (EU) requirements, the European Commission (2014, p.2) concludes that "[t]he impact of anti-corruption measures has so far been limited", and that "corruption remains prevalent in many areas and continues to be a serious problem" (European Commission 2016, p.4). Therefore, Montenegro must continue to strengthen its formal institutions while tackling corruption and creating an institutional framework that fosters more productive entrepreneurship.

As outlined above, the aim of this paper is to examine how the institutional environment impacts the nature of corruption affecting entrepreneurship in transition economies. To do this we utilise a survey of 311 entrepreneurs and 15 in-depth interviews with entrepreneurs across Montenegro. A database of contacts was drawn from the Central Register of the Economic Subjects in Podgorica, and from this 311 businesses from 11 different Montenegrin municipalities took part in interviews. The sample contains a range of demographic characteristics, company activities and size. Interviews were conducted with Directors, owners or authorised company representatives. Face-to-face interviews were carried out with each of the respondents, with the questionnaires lasting 30 minutes on average. The survey was conducted in 2009, three years after Montenegro became an independent state. Table 1 sets out the profile of the survey respondents.

In order to gain further insight into entrepreneurship and corruption in Montenegeo, in-depth interviews were carried out with a further 15 businesses, all of whom were based in the capital city of Podgorica. In emerging economies qualitative research has the potential to improve understanding of entrepreneurs' experiences, as well as provide rich data (Doern 2009).

Table 1: Profile of survey respondents

\begin{tabular}{|l|r|r|}
\hline & \multicolumn{1}{|c|}{ N } & \multicolumn{1}{|c|}{$\%$} \\
\hline Regions & 87 & 28 \\
\hline Podgorica & 36 & 11 \\
\hline Nikšić & $\mathbf{1 2 3}$ & $\mathbf{3 9}$ \\
\hline CENTER & 25 & 8 \\
\hline Bijelo Polje & 20 & 6 \\
\hline Pljevlja & 18 & 5 \\
\hline Berane & 15 & 4 \\
\hline Rožaje & $\mathbf{7 8}$ & $\mathbf{2 5}$ \\
\hline NORTH & 23 & 7.4 \\
\hline Bar & 21 & 6.8 \\
\hline Herceg Novi & 15 & 4.8 \\
\hline Kotor & 21 & 6.8 \\
\hline Ulcinj & 30 & 9.6 \\
\hline Budva & $\mathbf{1 1 0}$ & $\mathbf{3 5}$ \\
\hline SOUTH & $\mathbf{3 1 1}$ & $\mathbf{1 0 0}$ \\
\hline TOTAL & & \\
\hline & & \\
\hline Year of establishment & 52 & 18 \\
\hline Before 1996 & 60 & 21 \\
\hline 1997-2000 & 60 & 21 \\
\hline $2001-2003$ & 50 & 17 \\
\hline $2003-2005$ & 67 & 23 \\
\hline $2006-2009$ & & 100 \\
\hline TOTAL & & \\
\hline
\end{tabular}


Table 1: Continued

\begin{tabular}{|c|c|c|}
\hline & $\mathrm{N}$ & $\%$ \\
\hline \multicolumn{3}{|l|}{ Number of employees } \\
\hline $1-2$ & 72 & 23 \\
\hline $3-4$ & 52 & 17 \\
\hline $5-9$ & 63 & 21 \\
\hline $10-16$ & 58 & 19 \\
\hline $17-100$ & 57 & 19 \\
\hline $100+$ & 4 & 1 \\
\hline TOTAL & 306 & 100 \\
\hline \multicolumn{3}{|l|}{ Ownership } \\
\hline Domestic capital & 294 & 95 \\
\hline Foreign capital & 10 & 3 \\
\hline Mixed capital & 6 & 2 \\
\hline TOTAL & 310 & 100 \\
\hline \multicolumn{3}{|l|}{ Main activity } \\
\hline Agriculture, forestry and water supply & 4 & 1.3 \\
\hline Hunting and fishing & 2 & 0.6 \\
\hline Processing industry & 15 & 4.9 \\
\hline Construction & 11 & 3.6 \\
\hline Wholesale & 117 & 38.0 \\
\hline Retail & 21 & 6.8 \\
\hline Hotels and restaurants & 27 & 8.8 \\
\hline Transportation & 17 & 5.5 \\
\hline Financial intermediation & 9 & 2.9 \\
\hline Real estate and consulting & 5 & 1.6 \\
\hline Crafts & 50 & 16.2 \\
\hline Other (education, health services, etc) & 30 & 9.7 \\
\hline TOTAL & 308 & 100 \\
\hline \multicolumn{3}{|l|}{ Annual turnover } \\
\hline$<€ 50,000$ & 118 & 45 \\
\hline$€ 50,000-€ 100,000$ & 47 & 18 \\
\hline$€ 100,000-€ 200,000$ & 23 & 9 \\
\hline$€ 200,000-€ 400,000$ & 22 & 8 \\
\hline$€ 400,000-€ 600,000$ & 15 & 6 \\
\hline$€ 600,000-€ 800,000$ & 10 & 4 \\
\hline$€ 800,000-€ 1,000,000$ & 7 & 3 \\
\hline$>€ 1,000,000$ & 22 & 8 \\
\hline TOTAL & 264 & $100^{*}$ \\
\hline
\end{tabular}

* 101 due to rounding

As the full extent of corruption cannot be accurately measured (Budak and Rajh 2014), a mixed approach using surveys and qualitative interviews provides the opportunity to explore entrepreneurs' experiences and perceptions in great depth. While the small number of entrepreneurs limits generalisability, the value of the approach is in generating theoretical and policy implications for further research (Jack and Anderson 2002). The qualitative interviews were not intended to be representative of entrepreneurs in Podgorica or Montenegro, but rather to explore perceptions and experiences so that in-depth insights into their experiences of corruption could be gained. Potential participants were initially contacted via the Montenegro Chamber of Commerce, and then a snowball sampling technique was applied. Snowball sampling is a method particularly useful for undertaking research on sensitive topics and accessing 'hidden' populations and more suitable for small sample sizes (Hendricks and Blanken, 1992; Ram, Theodorakopoulos, and Jones, 2008). Table 2 profiles the participants in terms of their sector, size and age of their business. Interviews lasted 1 hour on average and were conducted in October 2014. Although the in-depth interviews were conducted five years after the survey, they add depth and voice to the study and offer a recent account of the level of corruption in Montenegro, allowing us to examine how the institutional environment has changed from post-independence in 2009 to the present context. The two data collection stages bridge two significant periods in Montenegro's evolution, i.e. the period when the state was still in its infancy and the period after the state committed to tackling corruption subsequent to starting EU accession negotiations in 2012. Therefore, the data enabled an evaluation of the prevailing level and perceptions of corruption in Montenegro and an assessment of the success achieved in mitigating corrupt activities.

The interviews were semi-structured which meant that a number of issues not on the interview schedule were raised by some respondents which were relevant and were subsequently explored further. The interviews were recorded with the respondent's consent. They were then transcribed, before a grounded approach was taken towards thematically analysing and coding the data to explore emergent themes. During the interviews, the entrepreneurs were asked to reflect on their business development, growth aspirations, and experiences/perceptions of corruption. As Doern and Goss (2013) state, one limitation of such an approach is the risk of fundamental attribution error, in that respondents might offer accounts of past actions or future intentions in terms that protect their self-image as entrepreneurs rather than recounting actual events, for example attributing barriers/challenges to the actions of others rather than to their own shortcomings. However, although such biases 
Table 2: Profile of in-depth interview respondents

\begin{tabular}{|l|l|c|l|}
\hline $\begin{array}{c}\text { Respon- } \\
\text { dent }\end{array}$ & \multicolumn{1}{|c|}{ Sector } & $\begin{array}{c}\text { Size of business } \\
\text { (number of employees) }\end{array}$ & \multicolumn{1}{|c|}{$\begin{array}{c}\text { Age of } \\
\text { business }\end{array}$} \\
\hline INT1 & Food and drink & $11-50$ & $6-10$ years \\
\hline INT2 & Electronics & $1-10$ & $6-10$ years \\
\hline INT3 & Food and drink & $1-10$ & $1-5$ years \\
\hline INT4 & Media & $11-50$ & $6-10$ years \\
\hline INT5 & Pharmaceutical & $1-10$ & $1-5$ years \\
\hline INT6 & Food and drink & $11-50$ & $6-10$ years \\
\hline INT7 & Electronics & $11-50$ & $1-5$ years \\
\hline INT8 & Food and drink & $1-10$ & Less than a year \\
\hline INT9 & Construction & $11-50$ & $6-10$ years \\
\hline INT10 & Construction & $51-250$ & $10+$ years \\
\hline INT11 & Financial services & $1-10$ & Less than a year \\
\hline INT12 & Media & $11-50$ & $6-10$ years \\
\hline INT13 & Retail & $1-10$ & $1-5$ years \\
\hline INT14 & IT & $1-10$ & $1-5$ years \\
\hline INT15 & Tourism & $1-10$ & $1-5$ years \\
\hline
\end{tabular}

Table 3: Level and perceptions of corruption

\begin{tabular}{|l|c|c|}
\hline & $\begin{array}{c}\text { N (out of } \\
311)\end{array}$ & $\%$ \\
\hline Level of corruption present & & \\
\hline Very present & 67 & 22 \\
\hline Present & 70 & 23 \\
\hline Somewhat present & 90 & 29 \\
\hline Not present & 58 & 19 \\
\hline Not present at all & 26 & 8 \\
\hline Most corrupt institutions & & \\
\hline Market inspection & 138 & 45 \\
\hline Customs administration & 135 & 43 \\
\hline Least corrupt institutions & & \\
\hline Tax administration & 39 & 13 \\
\hline Commercial Court & 35 & 11 \\
\hline Reasons for corruption & & \\
\hline Lack of professionalism/incompetence & 86 & 28 \\
\hline Complexity of procedures & 51 & 16 \\
\hline High cost of services & 43 & 14 \\
\hline Overwork & 25 & 8 \\
\hline Lack of transparency & 14 & 5 \\
\hline Don't know/no answer & 37 & 12 \\
\hline Other (e.g. low salaries, economic crisis) & 55 & 17 \\
\hline $\begin{array}{l}\text { Frequency of corrupt payments among those } \\
\text { who have had personal experience }\end{array}$ & & \\
\hline Paid a bribe/gift in past 12 months & & 22 \\
\hline $\begin{array}{l}\text { Expected to pay a bribe/gift in next 12 } \\
\text { months }\end{array}$ & & \\
\hline & & \\
\hline
\end{tabular}

cannot be ruled out completely, as the interviews allowed the respondents to recount their experiences in depth and for the interviewer to probe responses, a wholly artificial story would be very difficult to sustain. In carrying out qualitative research it is important that the reliability of coding is consistent and structured in order to prevent coder bias (Bryman 2012). As such, the coding process was conducted independently by the authors, with overarching thematic categories identified. Through this, a coding scheme was developed based on the key themes so that intra-coder reliability could be consistent. This coding scheme was then applied by all authors independently, with the results compared to ensure inter-coder reliability by identifying any discrepancies between the coders so that they could be revisited and then agreed. Such a constant comparative method involves continually identifying emergent themes against the interview data, and employing analytic induction so that the researcher can identify the nature of a relationship and develop a narrative (Silverman 2000; Bryman 2012). The qualitative approach enabled entrepreneurs to articulate how they perceive the interplay between institutions, corruption and their own entrepreneurial activity. Quotes from the interviews are used to add voice to the study.

\section{FINDINGS}

The remainder of the article presents the findings and analyses the experiences and perceptions of corruption of Montenegrin entrepreneurs. This section is divided into the following sub-sections: institutions as catalysts of corruption, highlighting how weak institutions create incentives to engage in corrupt practices; and the nature of corruption, from prevalent small bribes to large-scale corruption.

\section{Institutions as catalysts of corruption}

The survey uncovered the level of corruption that permeates formal and informal institutions in Montenegro. Survey respondents were asked a range of questions related to their perceptions of levels and types of corruption which impact on their entrepreneurial activities (Table 3). When asked to assess the level of corruption, $45 \%$ believed that corruption is present or very present. 
Entrepreneurs' responses highlight formal institutions as catalysts of corruption. The respondents who rated corruption as present or very present cited customs administration (43\% stating it was present or very present) and market inspection (45\% stating it was present or very present) as the most common areas of corruption. In identifying the reasons why these two institutions were characterised as the most corrupt, the problem of non-professionalism and/or incompetence of officials were recognised as a key issue (Table 3). Within this, corruption of individual staff is a key issue, as noted by the in-depth interviews. Highlighting the extent to which corruption permeates formal institutions, one respondent stated that: "People expect a bribe or favour. If you want something done, you need to comply" (INT3). At the same time, although the corruption of officials is a key issue, the high cost of services and the complexity of procedures, namely in the case of market inspection, along with a lack of transparency in the work of 'customs administration' are significant problems. Complexity is a key problem in transition economies where rules change quickly. In Montenegro's case complexity is further increased by the EU accession process whereby Montenegro needs to align its formal institutions to EU standards, and therefore the institutional landscape is constantly changing. One respondent stated: "There are new rules all of the time. It is hard to keep up with what you are supposed to adhere to" (INT6), while another stated that due to complexity he does not know whether he follows "all the rules ... I hope I do but maybe one day I will get a knock on my door to tell that I don't" (INT8).

Moreover, respondents also mentioned additional reasons for corruption, other than those put forward in the questionnaire as possible answers. The most frequently stated reasons were that officials are in a position to take bribes (24\%), that fact that officers have low salaries (20.7\%), and also that personal benefit is more important to them and comes before fairness when considering work performance (21\%). Many of the in-depth interview respondents stated that such activity leads to nepotism, with friends and family favoured over others. For example, one entrepreneur stated that "If you know someone in the office, then you get your paperwork through quickly. But if you don't it will be much slower" (INT10). Such perceptions mean that the entrepreneurs often perceived the system to be inherently 'unfair', with access to power and influence beneficial for some, but creating barriers to others: "Sometimes you can feel cut off if you don't have any contacts in the customs office or the tax office ... the progress of your business can be really slowed down by not having anyone to help" (INT12).
These findings reveal that petty corruption is often linked to nepotism rather than money.

Furthermore, when asked to assess their level of trust in the institutions with which they cooperate, the largest percentage of respondents stated that they have the highest level of trust in Tax Administration (13\%) and the Commercial Court (11\%). Taking into account that the estimated level of corruption in the two aforementioned institutions/services was the lowest, it is possible to conclude that enterprise representatives tend to indicate more confidence in the system institutions in which corruption is estimated at the lowest level.

Respondents were also asked to score the level of corruption in public services on a scale of 1-5 (where 1 is 'not present at all' and 5 is 'extremely present'), and based on their responses (Table 4) the most corrupt processes and services are Issuing of Construction Permits (3.2), Urbanization and Construction Inspections (3.1). Customs Administration and Spatial Planning were given a medium level mark of 2.9. The responses are supported by data from the World Bank (2017) which ranks Montenegro 93rd of 189 countries in terms of dealing with construction permits, with 8 procedures and 152 days required to obtain a permit. However, the World Bank (2017) reports that trading across borders is reported as fairly efficient in Montenegro, which contrasts the level of corruption reported by Montenegrin entrepreneurs in the Customs Administration department. Nevertheless, this discrepancy signals an improvement in this area between 2009 - the time the survey was conducted - and 2015 - the recent international ranking. On the other hand, company representatives believed that corruption is least present in the Commercial Court (2.2). When comparing the results by region, the level of corruption present in the process of obtaining concessions is rated much lower in the central region (1.8) than it is in the northern (3.3) and southern (2.8) regions. Though the least developed, the northern region faces a corruption level above the national average and above the score achieved by the other two regions, as perceived by the entrepreneurs. Since no large transactions are taking place in the least developed region, this emphasises that corruption in Montenegro is linked to nepotism rather than money.

Therefore weak formal institutions and perceptions of corruption give rise to opportunities to engage in corrupt practices which become a norm of doing business, benefiting those with resources and access to power while constraining the others. However, there are two sides to the story and the interviews highlight that the prevalence of corruption cannot be entirely attributed to weak formal institutions. 
Table 4: Average rating regarding the level of corruption in the following public service

\begin{tabular}{|c|c|c|c|c|}
\hline & Montenegro & Center & North & South \\
\hline Customs Administration & 2.9 & 3.0 & 3.1 & 2.9 \\
\hline Directorate for Public Procurement & 2.6 & 2.3 & 2.6 & 2.8 \\
\hline Tax Administration & 2.4 & 2.5 & 2.2 & 2.5 \\
\hline Issuance of Construction Permits & 3.2 & 3.3 & 3.1 & 3.2 \\
\hline Urbanism & 3.1 & 2.9 & 2.9 & 3.3 \\
\hline Spatial Planning & 2.9 & 2.8 & 2.9 & 3.1 \\
\hline Issuing Working Permits & 2.5 & 2.7 & 3.1 & 2.2 \\
\hline Construction Inspection & 3.1 & 3.1 & 2.8 & 3.3 \\
\hline Market Inspection & 2.8 & 3.5 & 2.2 & 2.5 \\
\hline Communal Police & 2.5 & 2.5 & 2.7 & 2.4 \\
\hline Labour Inspection & 2.4 & 2.7 & 2.2 & 2.2 \\
\hline Sanitary Inspection & 2.4 & 2.5 & 2.1 & 2.5 \\
\hline Tax Inspection & 2.4 & 2.6 & 2.2 & 2.4 \\
\hline Obtaining Concessions & 2.8 & 1.8 & 3.3 & 2.8 \\
\hline Judicial Authorities & 2.6 & 2.7 & 2.4 & 2.6 \\
\hline Commercial Court & 2.2 & 2.3 & 1.8 & 2.4 \\
\hline
\end{tabular}

Corruption instead is the results of a system that creates incentives for both poorly paid officers seeking personal benefits and for entrepreneurs constrained by complexity, high cost of services and the lack of transparency to engage in corrupt practices. As such, corruption becomes both expected and accepted, as highlighted in the following sub-section.

\section{The nature of corruption}

Small-scale bribery. Respondents were asked three different questions related to corruption to test their honesty and propensity to engage in corrupt practices, i.e. whether they offered a bribe in the past 12 months, whether they have been in a situation where a bribe was expected from them, and what they would do if they are asked to offer a bribe. While the perception that corruption was widespread was common among the respondents, the majority of companies who took part in the survey (88\%) stated that they did not give presents/bribes to officers within the past 12 months; $6 \%$ of respondents indicated that they rarely offered bribes, while $4 \%$ indicated that they had often offered bribes to competent authorities over the past 12 months. Moreover, when asked whether a bribe was expected from them in return for some service, $18 \%$ confirmed, out of which $21 \%$ offered a bribe, $41 \%$ said they did not offer a bribe, and a significant group - 38\% - refused to answer (Table 5). Of the total number of companies that had given bribes, six companies stated that they had given bribes to customs officers and to market inspection officers. The highest value of a bribe offered to a customs officer was $€ 300$, whilst the highest amount that a market inspection officer was offered was $€ 500$. The main benefit of bribery, according to the survey respondents, is the speeding up of procedures, followed by the avoidance of responsibility in terms of non-compliance with rules as well as the reduction of outstanding liabilities (Table 5). The fact that market inspection was reported to be one of the most corrupt institutions by almost half of the respondents shows not only the level of corruption to which the institution is subject but also the participation of entrepreneurs in corrupt practices, who take advantage of officers' low salaries and offer them small bribes in order to avoid penalties. Thus petty corruption is both expected and accepted. The problems solved by offering bribes emphasise some of the issues encountered by entrepreneurs when having to deal with formal institutions, and the relatively low value of bribes demonstrates that the majority of bribes paid are small-scale. Similarly, the indepth interviews found that small-scale bribery was prevalent, with only one respondent stating that they paid a bribe of over $€ 1000$. To many of the in-depth respondents, paying small-scale bribes was a necessary aspect of ensuring that paperwork, particularly relating to licenses, was approved. One respondent stated that "sometimes you have to pay a bribe, but it won't affect you much. It will only be a few hundred Euros in order to get things processed on time" (INT15), while 
Table 5: Frequency and benefits of paying bribes

\begin{tabular}{|c|c|}
\hline Frequency of opportunities to give a bribe among those who gave a bribe & $\%$ \\
\hline $1-2$ times & 50 \\
\hline 3-5 times & 29 \\
\hline 5-10 times & 9 \\
\hline More than 10 times & 12 \\
\hline \multicolumn{2}{|l|}{ Actions of companies where bribes/corruption were expected } \\
\hline Offered a gift/bribe & 21 \\
\hline Did not offer a gift/bribe & 41 \\
\hline Don't want to answer & 38 \\
\hline \multicolumn{2}{|l|}{ Response of companies if bribe/corruption would be expected } \\
\hline Would refuse to offer a bribe & 41 \\
\hline Would give a bribe & 21 \\
\hline Don't know/Undecided & 38 \\
\hline \multicolumn{2}{|l|}{ Act of payment/bribery initiators } \\
\hline Officers who are in direct contact with parties & 47 \\
\hline Higher officers in institution/departments & 11 \\
\hline Parties (management or employees in the companies) & 36 \\
\hline Someone else & 6 \\
\hline \multicolumn{2}{|l|}{ Benefits of paying bribes } \\
\hline Faster processing of procedures & 32 \\
\hline Avoiding responsibility (misdemeanour, criminal, etc.) & 27 \\
\hline Decreasing due obligations (taxes, duties, fees, etc.) & 16 \\
\hline Lower tariffs/ payment of required services & 8 \\
\hline There was no other alternative way & 8 \\
\hline Obtaining services for which the company does not meet conditions & 5 \\
\hline Other reasons & 4 \\
\hline
\end{tabular}

another said "you don't really think about because the amounts are small. If I pay $€ 100$ to get a license sorted I don't really worry about it ... it is not right but it does not act as a major barrier" (INT12). In this sense, the formal institutions are permeated with informal practices in that corrupt practices are expected and accepted (Spicer 2009). As Tonoyan et al. (2010) state, if the perception is that corruption is rife, the expectation will be that the 'moral costs' are low in terms of being socially sanctioned. Corruption through bribes thus takes the form of accepted insurance payments to ensure that formal institutions do not constrain entrepreneurial activity. Many of the respondents accepted the fact that bribes needed to be paid and were not concerned by them due to the relatively small amounts involved. Perhaps the small value of bribes is in itself part of the reason why bribery became a prevalent and accepted practice, influencing perceptions to the extent where the benefits gained from participating in the process outweighed the monetary and moral costs. One of the surveys showed that around one out of eight (12 per cent) bribes paid serve no specific immediate purpose for the businesses paying them, suggesting that these are "sweeteners" given to public officials to "groom" them for future interactions in the interest of the company.

Large-scale bribery. At the same time, the in-depth respondents stated that large-scale bribery did take place but that, as one respondent said, "it is not part of our world" (INT3). Large-scale bribes were seen to be related to large, sometimes multinational companies that benefit from close contacts with public officials. As reported by the US Department of State (2016) in the most recent report on Human Rights Practices in Montenegro, though regulation provides criminal penalties for corruption by officials, the law remains implemented ineffectively, and corruption remains the problem. As stated in the report "politicization, poor salaries, and lack of motivation and training of public servants provided fertile ground for corruption" (p.18). During 2016, several cases of "high level corruption" have been processed and investigated, showing strong connection between politicians and businesses. Despite not involving small entrepreneurs, such cases cause lack of trust in institutions and impact entrepreneurial behaviour by preventing new investments and job creation.

The waves of privatisation in Montenegro led to the exit of numerous productive and small enterprises (Koman et al. 2015) and blurred the lines 
between state official's public and private interests (Uzelac 2003). At the same time, it created a mechanism whereby new or privatised companies with direct links with the government were able to gain unfair market advantages. This in turn created a system whereby large companies can control their markets by using formal institutions to undermine the activities of their competitors or even eliminate them from the market. The World Economic Forum (2016) shows that, in terms of goods market efficiency, Montenegro ranks significantly lower on intensity of local competition, and lower on extent of market dominance and effectiveness of anti-monopoly policy. It is possible that important players use market inspection to keep smaller players under control, limiting their activities and creating a system where only those who comply with corruption can continue to operate. The in-depth interviewees stated that large players could act to prevent smaller businesses growing to large, mainly by utilising their contacts with government. This meant that smaller businesses were crowded out from public procurement contracts. For example, when publishing public tenders, conditions are set up to simply eliminate small companies by introducing technical specifications which can be met only by certain bidders or by providing unrealistic prices which are much lower compared to the ones on the market (MEF, 2016). As one respondent stated, "we can't hope to compete for public contracts, we have given up on that. A larger business that is prepared to pay larger bribes or use their contacts will always win" (INT4). As shown in Table 5, both officers (47\%) and companies $(36 \%)$ are frequent bribery initiators and therefore it is rather clear that corruption is based on a mutual understanding between public authorities and private interests, creating non-transparent channels of influence whereby only those who can afford the price and have political connections can succeed.

\section{CONCLUSION}

This article has examined the nature of corruption affecting entrepreneurship in Montenegro, a transitional economy with an emerging institutional environment. The study contributes to a better understanding of institutional development in countries which are aiming to transition towards a more open market economy and of how legacies of corruption permeate formal and informal institutions stymie productive entrepreneurial activity. We show that regardless of whether entrepreneurs try to act strategically to take advantage of corrupt opportunities or endeavour to avoid corrupt activities, the interplay between formal and informal institutions means that corruption is embedded. As such, entrepreneurs almost inevitably become subject to the corrupt practices of others. Some accept it as a normal aspect of the culture, while others engage in it as perpetrators. Corruption is facilitated by complicated procedures and weak informal institutions which act as catalysts of corrupt activities, creating incentives for both officials and entrepreneurs to engage in corrupt practices. The nature of corruption in Montenegro affects all entrepreneurs, irrespective of the size of their ventures, and corrupt practices range from small-scale almost incidental bribery and nepotism to large-scale activities.

Often corruption involves small bribes which are not perceived as a problem by entrepreneurs, but rather as an accepted part of doing business. In this way, petty corruption acts as an insurance payment compensating for institutional failure, as bribes can ensure that entrepreneurial activity is not directly constrained by institutional inefficiencies. Petty corruption is often liked to nepotism rather than money, and entrepreneurs can turn to informal networks to circumvent or speed up complex bureaucratic procedures and to obtain preferential deals (Williams and Yang 2017). Large-scale financial corruption mostly affects large businesses with links to the government and involves public contracts for which small businesses usually cannot compete. Moreover, even though most entrepreneurs do not experience corruption on a day-to-day basis, perceptions of corruption perpetuate corrupt practices and hinder the convergence of formal and informal institutions. In addition, corruption prevents safe and rational investment, both foreign and domestic; it slows down and hinders development and limits trade, leads to irrational and wasteful use of public funds, encourages the "gray" economy, and reduces tax sources (Vorley and Williams 2016).

Transitioning from a formerly centrally planned economy and only experiencing independence for the past decade, Montenegro's institutional framework remains underdeveloped. Montenegro's independence, albeit an important step towards a more open market economy, was used as an opportunity by private interests to influence the development of institutions to shape the 'rules of the game' to their own advantage. Moreover, the waves of privatisation blurred the lines between private and public interests, creating unfair, non-transparent channels of access to power and influence. Therefore legacies of corruption continue to hinder entrepreneurship in Montenegro and its ability to contribute to economic development, and to permeate formal and informal institutions, maintaining perceptions of corruption and perpetuating 
corrupt practices which became accepted as a norm of doing business. Our paper finds that, despite some progress being made in strengthening its formal institutions and improving its legislative framework, reforms have not adequately tackled corruption, which remains prevalent. This is confirmed by the majority of Montenegrin entrepreneurs who are either convinced that the fight against corruption has been unsuccessful or are unsure about its effects.

Given the prevalence of corruption in Montenegro, strengthening formal institutions, changing perceptions of corruption, and achieving congruence between formal and informal institutions is undoubtedly a long-term process. Despite further progress being expected as part of its accession negotiations, perceptions of corruption are likely to persist unless Montenegro achieves a credible track record of fighting against corruption. Understanding how Montenegro and other transition economies can break free from legacies of corruption to harness entrepreneurship as a catalyst of economic development represents a fruitful avenue for future research.

\section{REFERENCES}

Acs, Z.J., O'Gorman, C., and Szerb, L. 2007. Could the Irish miracle be repeated in Hungary?, Small Business Economics 28(2):123-142.

Acs, Z.J., Desai, S. and Hessels, J. 2008. Entrepreneurship, economic development and institutions. Small Business Economics 31(3): 219-234.

Ahlstrom, D. and Bruton, G.D. 2002 An institutional perspective on the role of culture in shaping strategic actions by technology-focused entrepreneurial firms in China. Entrepreneurship Theory Practice 26(4): 53-70.

Aidis, R. and Adachi, Y. 2007. Russia: firm entry and survival barriers. Economic Systems 31(4): 391-411.

Aidis, R., Estrin, S., and Mickiewicz, T. 2008. Institutions and entrepreneurship development in Russia: a comparative perspective. Journal of Business Venturing 23(6): 656-672.

Andelic, G. Cosic, I. and Dakovic, V. 2010. The impact of globalisation on the insurance and reinsurance market of Eastern Europe. South East European Journal of Economics and Business 5(1) 95-112.

Andvig, J.C. and Moene, K.O. 1990. How corruption may corrupt. Journal of Economic Behavior \& Organization 13(1): 63-76.

Anokhin, S. and Schulze, W.S. 2009. Entrepreneurship, innovation and corruption. Journal of Business Venturing 24(5): 465-476.

Basu S., Estrin, S. and Svejnar, J. 2005. Employment determination in enterprises under communism and in transition: evidence from Central Europe. Industrial Labor Relations Review 58(3): 353-369.

Baumol, W.J. 1990 Entrepreneurship: productive, unproductive and destructive. Journal of Political Economy 98(5): 892-921.

Becker, G.S. 1968. Crime and punishment: an economic approach. Journal of Political Economy 76(2): 169-217.

Bobera, D., Lekovic, B. and Berber, N. 2014. Comparative analysis of entrepreneurship barriers: findings from Serbia and Montenegro. Inzinerine Ekonomika-Engineering Economics 25(2):167-176.

Broadman, H.G. and Recanatini, F. 2000. Seeds of corruption: do market institutions matter? MOST: Economic Policy in Transitional Economies 11(4):359-392.

Bruton, G.D., Ahlstrom, D. and Obloj, K. 2008. Entrepreneurship in emerging economies: where are we today and where should the research go in the future. Entrepreneurship Theory Practice 32(1): 1-14.

Bryman, A. 2012. Social Research Methods, 4th edition. Oxford: Oxford University Press.

Budak, J. and Rajh, E. 2014. Corruption as an obstacle for doing business in the Western Balkans: a business sector perspective. International Small Business Journal 32(2):140-157.

Cowen, T. and Coyne, C.J. 2005. Postwar reconstruction: some insights from public choice and institutional economics. Constitutional Political Economy 16(1): 31-48.

Chowdhury, F. Audretsch, D.B. and Belitski, M. 2015. Does corruption matter for international entrepreneurship? International Entrepreneurship and Management Journal 11(4): 959-980.

DiMaggio, P.J. and Powell, W.W. 1983. The iron cage revisited: institutional isomorphism and collective rationality in organizational fields. American Sociological Review 48(2): 147-160.

Doern, R. 2009. Investigating barriers to SME growth and development in transition environments: a critique and suggestions for developing the methodology. International Small Business Journal 27(3): 275-305.

Doern R, and Goss, D. 2014. The role of negative emotions in the social processes of entrepreneurship: power rituals and shame-related appeasement behaviours. Entrepreneurship Theory and Practice 38(4): 863-890.

Efendic, A., Pugh, G. and Adnett, N. 2011. Confidence in formal institutions and reliance on informal institutions in Bosnia and Herzegovina: an empirical investigation using survey data. Economics of Transition 19(3): 521-540.

Efendic, A., Mickiewicz, T. and Rebmann, A. 2015. Growth aspiration and social capital: young firms in a post-conflict environment. International Small Business Journal 33(5): 537-561.

Estrin, S. and Mickiewicz, T. 2011. Entrepreneurship in transition economies: the role of institutions and generational change. In The dynamics of entrepreneurship, edited 
by M. Minniti, 181-208. Oxford: Oxford University Press: Oxford.

Estrin, S., Korosteleva, J. and Mickiewicz, T. 2013. Which institutions encourage entrepreneurial growth aspirations? Journal of Business Venturing 28(4): 564-580.

European Commission (2014) Montenegro progress report. https://ec.europa.eu/. (accessed September 2, 2017).

European Commission (2016) Montenegro 2016 report. https://ec.europa.eu/. (accessed September 2, 2017).

Gerring, J. and Thacker, S.C. 2005. Do neoliberal policies deter political corruption?. International Organization 59(1): 233-254.

Goel, R.K. and Nelon, M.A. 2005. Economic freedom versus political freedom: cross-country influences on corruption. Austrian Economic Papers 44(2):121-133.

Guseva, A. 2007. Friends and foes: informal networks in the Soviet Union. East European Quarterly 41(1): 2-9.

Hellman, J.S. and Kaufmann, D. 2001. Confronting the challenges of state capture in transition economies. Finance and Development Quarterly 38(3). http://www.imf.org/ external/pubs/ft/fandd/2001/09/hellman.htm. (accessed September 2, 2017).

Hendricks, V.M. and Blanken, P. 1992. Snowball Sampling: Theoretical and Practical Considerations. In Snowball sampling: A pilot study on cocaine use. Edited by V.M. Hendricks. Rotterdam: IVO.

Henrekson, M. 2007. Entrepreneurship and institutions. Comparative Labor Law and Policy Journal 28(4): 717-742.

Heritage Foundation. 2017. 2017 Index of Economic Freedom. The Heritage Foundation: Washington, DC.

Hudson, J., Williams, C.C., Orviska, M. and Nadin, S. (2012) Evaluating the impact of the informal economy on businesses in South East Europe: Some lessons from the 2009 World Bank Enterprise Survey, South East European Journal of Economics and Business, 7(1) 99-110

Hunt, J. and Laszlo, S. 2012. Is bribery really regressive? Bribery's costs, benefits, and mechanisms. World Development 40(2): 355-372.

Imami, D. (2012) Corruption, licensing and elections - a new analysis framework. South East European Journal of Economics and Business 7(1) 93-97.

Jack, S.L. and Anderson, A.R. 2002. The effects of embeddedness on the entrepreneurial process. Journal of Business Venturing 17(5): 467-487.

Koman, M., Lakićević, M., Prašnikar, J. and Svejnar, J. 2015. Asset stripping and firm survival in mass privatization: testing the Hoff-Stiglitz and Campos-Giovannoni models in Montenegro. Journal of Comparative Economics 43(2): 274-289.

Krasniqi, B.A. and Mustafa, M. 2016. Small firm growth in a post-conflict environment: The role of human capital, institutional quality, and managerial capacities.
International Entrepreneurship and Management Journal 12(4) 165-1207.

Ledeneva, A. 1998. Russia's economy of favors: blat, networking and informal exchange. Cambridge: Cambridge University Press.

Luo, Y. 2005. An organizational perspective of corruption. Management and Organization Review 1(1):119-154

Luo, Y. and Junkunc, M. 2008. How private enterprises respond to government bureaucracy in emerging economies: the effects of entrepreneurial type and governance. Strategic Entrepreneurship Journal 2(2):133-153.

Manolova, T.S. and Yan, A. 2002. Institutional constraints and strategic responses of new and small firms in a transforming economy: the case of Bulgaria. International Small Business Journal 20(2): 163-184.

Manolova, T.S., Eunni, R.V. and Gyoshev, B.S. 2008. Institutional environments for entrepreneurship: evidence from emerging economies in Eastern Europe. Entrepreneurship Theory and Practice 32(1): 203-218.

Montenegrin Employers Federation (MEF) 2016. Report: corruption in Montenegro - the enabling environment for sustainable enterprises in Montenegro. Podgorica: Montenegrin Employers Federation.

Montinola, G.R. and Jackman, R.W. 2002. Sources of corruption: a cross-country study. British Journal of Political Science 32(1):147-170

North, D.C. 1990. Institutions, institutional change, and economic performance. Cambridge: Cambridge University Press.

Paldam, M. 2002. The cross-country pattern of corruption: economics, culture and the seesaw dynamics. European Journal Political Economy 18(2): 215-240.

Pejovich, S. 1999. The effects of the interaction of formal and informal institutions on social stability and economic development. Journal of Markets and Morality 2(2):164-181

Pinto, R. 2005. Challenges for public policy in promoting entrepreneurship in south eastern Europe. Local Economy 20(1): 111-117.

Puffer, S.M., McCarthy, D.J. and Boisot, M. 2010. Entrepreneurship in Russia and China: the impact of formal institutional voids. Entrepreneurship Theory and Practice 34(3):441-467.

Ram, M. Theodorakopoulos, N. and Jones, T. 2008. Forms of capital, mixed embeddedness and Somali enterprise. Work, Employment and Society 22(3): 427-446.

Rose-Ackerman, S. 2001. Trust and honesty in post-socialist societies. Kyklos 54(2-3): 415-443.

Round, J. and Williams, C.C. 2010. Coping with the social costs of 'transition': everyday life in post-Soviet Russia and Ukraine. European Urban and Regional Studies 17(2): 183-196.

Scott, S. 2007. The community morphology of skilled migration: the changing role of voluntary and community 
organisations (VCOs) in the grounding of British migrant identities in Paris (France). Geoforum 38(4): 655-676.

Shleifer, A. and Vishny, R.W. 1993. Corruption. Quarterly Journal of Economics 108(3): 599-617.

Silverman, D. 2000. Doing Qualitative Research. London: Sage.

Smallbone, D. and Welter, F. 2001. The distinctiveness of entrepreneurship in transition economies. Small Business Economics 16(4): 249-262.

Spicer, A. 2009. The normalization of corrupt business practices: implications for Integrative Social Contracts Theory (ISCT). Journal of Business Ethics 88(4):833-840.

Swamy, A., Knack, S., Lee, Y. and Azfar, O. 2000. Gender and corruption. Journal of Development Economics 64(1):25-55

Tonoyan, V., Strohmeyer, R., Habib, M. and Perlitz, M. 2010. Corruption and entrepreneurship: how formal and informal institutions shape small firm behavior in transition and mature market economies. Entrepreneurship Theory and Practice 34(5):803-831.

Transparency International. 2016. Corruption Perceptions Index 2016. Transparency International: Berlin

Treisman, D. 2000. The causes of corruption: a cross-national study. Journal of Public Economics 76(3): 399-457.

US Department of State (2016) Country reports on human rights practices for 2016: Montenegro. https://www. state.gov/documents/organization/265666.pdf. (accessed September 2, 2017)

Uzelac, S. 2003. Corruption in transition countries: "how to capture a state" - the example of Montenegro. South-East Europe Review for Labour and Social Affairs 6(1/2):103-116.

Vorley, T. and Williams, N. 2016. Between petty corruption and criminal extortion: how entrepreneurs in Bulgaria and Romania operate within a devil's circle. International Small Business Journal 34(6):797-817.
Welter, F. 2011. Contextualising entrepreneurship: conceptual challenges and ways forward. Entrepreneurship Theory and Practice 35(1): 165-184.

Welter, F. and Smallbone, D. 2011. Institutional perspectives on entrepreneurial behavior in challenging environments. Journal of Small Business Management 49(1): 107-125.

Williams, C.C., Franic, J. and Dzhekova, R. 2015. Explaining the undeclared economy in Bularia: An institutional asymmetry perspective. South East European Journal of Economics and Business 9(2): 33-45.

Williams, C.C. and Yang, J. 2017. Evaluating the use of personal networks to circumvent formal processes: A case study of vruzki in Bulgaria. South East European Journal of Economics and Business 12(1): 57-67.

Williams, N. and Vorley, T. 2015. Institutional asymmetry: how formal and informal institutions affect entrepreneurship in Bulgaria. International Small Business Journal 33(8): 840-861

Williams, N. and Vorley, T. 2017. Fostering productive entrepreneurship in post-conflict economies: The importance of institutional alignment. Entrepreneurship and Regional Development, online first, DOI: 10.1080/08985626.2017.1297853

World Bank (2000) Anticorruption in transition: a contribution to the policy debate. http://documents.worldbank. org/curated/en/home. (accessed September 2, 2017).

World Bank. 2017. Doing business 2017: equal opportunities for all. World Bank: Washington, DC

World Economic Forum. 2016. The global competitiveness report 2016-2017. World Economic Forum: Geneva, Switzerland

Xheneti, M., Smallbone, D. and Welter, F. 2012. EU enlargement effects on cross-border informal entrepreneurial activities. European Urban and Regional Studies 20(3): 314-328. 